\title{
Diurnal and Seasonal Variation of Surface Refractivity in Minna and Lapai, North Central Nigeria
}

\author{
*Tyabo M. A. ${ }^{1}$, Oyedum O. D. ${ }^{1}$, Bashir Musa ${ }^{1}$, Muraina Nurudeen ${ }^{1}$ and Ibrahim Samuel ${ }^{2}$ \\ ${ }^{1}$ Physics Department, Federal University of Technology, Minna, Niger State, Nigeria \\ ${ }^{2}$ Geography Department, Ibrahim Badamasi Babangida University, Lapai, Nigeria
}

\begin{abstract}
Spatial and temporal variations of surface refractivity, Ns, in the troposphere are important parameters in designing terrestrial communication links. This research work examines the effect of variations of meteorological parameters on surface radio refractivity during dry and wet seasons in Minna and Lapai (2011-2013). The data on surface temperature, humidity and pressure collected from the Tropospheric Data Acquisition Network (TRODAN) weather stations installed at the Federal University of Technology, Minna, and at Ibrahim Badamasi Babangida University, Lapai, were used for the computation of radio refractivity. The hourly and monthly averages of radio refractivity during dry and wet seasons were calculated. The results showed that surface refractivity varied diurnally and seasonally in both stations. Refractivity values were high during the early morning and night hours and decreased rapidly during the afternoon hours. Values of refractivity were also generally low during the dry season months and high during the wet season months. It was also observed that refractivity values were higher at Lapai than Minna in dry season months. The result also shows that diurnal refractivity variation is attributed to atmospheric phenomena while seasonal variation is caused by the climatic conditions of the regions. Maximum values of $350 \mathrm{~N}$-units in August in 2011, $343 \mathrm{~N}$-units in July in 2012 and $347 \mathrm{~N}$-units in August in 2013, while the minimum values of $275 \mathrm{~N}$-units in January in 2011,278 $\mathrm{N}$-units in March in 2012 and $273 \mathrm{~N}$-units were recorded in February for Minna. Surface refractivity has maximum values of 350 N-Units in August (2011), 347 N-Units in August (2012) and 349 N-Units in September (2013), while minimum values of 289 NUnits, 290 N-Units and 297 N-Units occurred in January in 2011, 2012 and 2013 respectively for Lapai.
\end{abstract}

Keywords : Troposphere, Diurnal, Seasonal, Temperature, Humidity, Pressure, Troposphere, Radio refractivity, Minna, Lapai.

\section{INTRODUCTION}

Radio waves suffer different forms of degradation in the atmosphere (troposphere). Common examples are reflection, absorption, scattering and refraction. The refractive index of the troposphere is an important factor in predicting the performance of terrestrial radio links. Refractive index variations of the atmosphere affect radio frequencies above $30 \mathrm{MHz}$, although these effects become significant only at frequencies greater than about $100 \mathrm{MHz}$ especially in the lower atmosphere. Changes in the value of the radio refractive index can curve the path of the propagating radio wave. At standard atmospheric conditions near the Earth's surface, the surface radio refractive index is approximately 1.0003 (6). Since the value of refractive index is almost unity, then the refractive index of air in the troposphere is often measured by a quantity called the radio-refractivity $\mathrm{N}$, which is related to refractive index, $\mathrm{n}$ as (7):

$$
\text { 圆 }=(\text { 回 }-1) \times 10^{6}
$$

The multiplication factor are used because the refractive index of air, $n$ deviates from unity by at most a few parts per ten thousand (5). As the conditions of propagation in the atmosphere vary, the interference of radio-wave propagation is observed. Such interferences are incident with some meteorological parameters such as temperature, high evaporation and humidity, passing of the cold air over the warm surface and vice-verse (4). 
Radio waves travel through vacuum with a speed equal to the speed of light. In material medium, the speed of the radio waves is approximately where $\mathrm{c}$ is the speed of light in vacuum and $\mathrm{n}$ is the radio refractive index of the medium. The value of radio refractive index (n) for dry air is almost the same for radio waves and light waves.

The surface refractive index depends on air temperature, humidity, atmospheric pressure and water vapour pressure (8). Variation in any of these meteorological parameters can make a significant variation on radio wave propagation, because radio signals can be refracted over whole signal path. Subsequently, meteorological data depend on the height at a point above the ground surface. According to (3) studied the diurnal and seasonal variations of surface refractivity over Nigeria. The result shows that surface refractivity has higher values during the rainy season than during the dry season. 13 worked on the empirical evaluation of refractivity in Nigeria. Their results showed that Northern Stations in Nigeria have lower refractivity values and Southern Stations have higher refractivity values. 10 showed that reduced-to-sea-level refractivity in Minna has considerable diurnal and seasonal tendencies: maximum values occurred in the night while minimum values occur towards the evening. Also, a seasonal trend of higher values in rainy season and lower values in dry season was also observed. This seasonal trend is in agreement with other reports on Nigerian stations, including other works such as 1 or 9.

This work is, therefore, aimed at finding out the diurnal and seasonal variation of meteorological parameters with the surface refractivity in dry and wet seasons at Minna and Lapai respectively for the period 2011-2013. The improvement of this work on previous work is the uses of local meteorological parameters was employed especially in Lapai were much work has been done.

\section{CLIMATIC CHARACTERISTICS OF THE STUDY AREA}

Minna and Lapai is situated in the tropics at Lat $9^{\circ} 24^{d} \mathrm{~N} /$ Long $6^{\circ} 25^{\mathrm{d}} \mathrm{E}$ and Lat $9^{\mathrm{o}} 3^{\mathrm{d}} \mathrm{N} / \mathrm{Long} 6^{\mathrm{o}} 3^{\mathrm{d}} \mathrm{E}$ in the North central part of Nigeria. The climatic condition of the study area is almost the same and the weather condition can be generally characterised into wet season, from April to October and dry season, from November to March; an agricultural trade centre with light/no industries and is partially or not influenced by industrial pollutants.

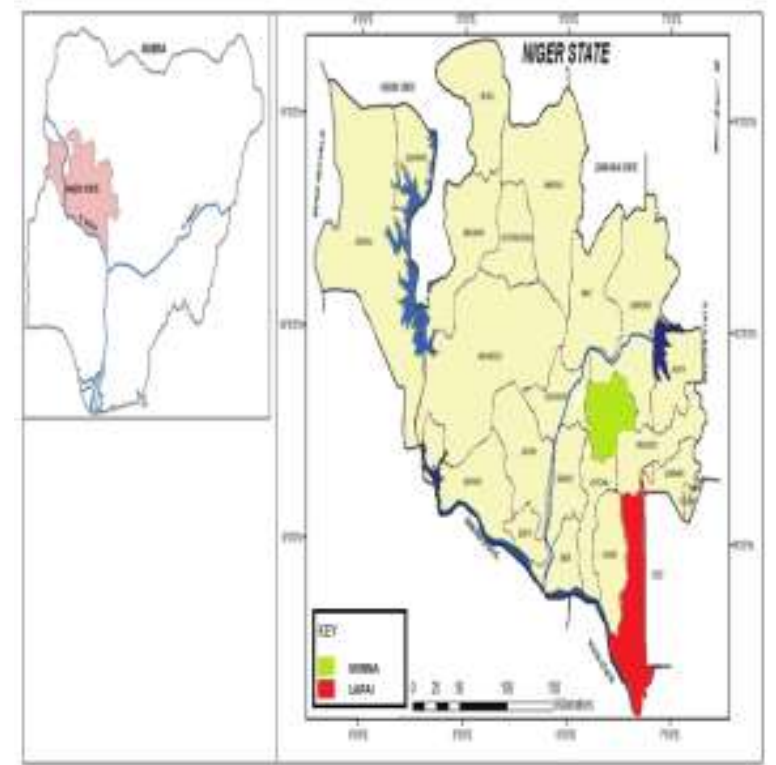

Map 1. Map of Nigeria showing Minna (GIS Maps)

\section{METHODOLOGY}

The meteorological parameters (pressure, temperature and relative humidity) used to calculate surface refractivity for Minna and Lapai were provided by Campbell weather stations installed at Federal University Technology, Minna, and at Ibrahim Badamasi Babangida University, Lapai.

The analysis were done in all the months of the year (2011-2013), but the months of January and August results were chosen to represent the dry and wet season in North Central Nigeria. The diurnal and seasonal variations of meteorological parameters for five minute (5min) interval were recorded for wet and dry seasons in Minna and Lapai. The water vapour pressure (迢) was calculated using the formula: 


$$
\text { 圆 }=\frac{\text { 国 } \times \text { 国国 }}{100}
$$

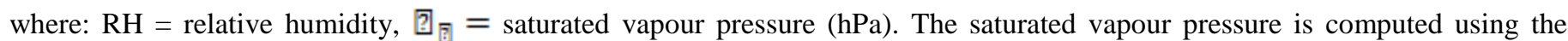
formula:

$$
\text { 回国 }=6.11 \text { 国回回 }\left(\frac{17.26(\text { 还 }-273.16)}{\text { 曰-35.87 }}\right)
$$

where: $\mathrm{t}=$ temperature $\left({ }^{\circ} \mathrm{C}\right)$

In relation with the measured meteorological parameters such as the temperature, pressure and relative humidity radio refractivity was calculated using:

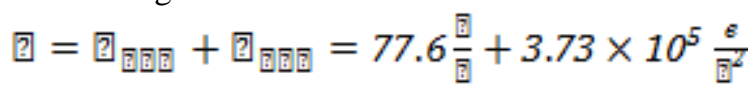

where:

圆 $=$ Atmospheric pressure $(\mathrm{hPa})$ and $\left[\begin{array}{l}\text { [ } \\ =\end{array}\right.$

Equation (4) may be employed for the propagation of radio frequencies up to $100 \mathrm{GHz}$ (8). The error associated with the application of the above formula is less than $0.5 \%$.

\section{RESULTS AND DISCUSSION}

The data obtained from Campbell weather stations for the period of three (3) year(s) (2011-2013) was used in calculating averages of hourly and monthly variations of surface refractivity in Minna and Lapai using Microsoft Excel. The plots of diurnal variations of surface refractivity for both dry and wet season are shown in Figures $1-6$ below.

From the Figures 1, 2, 3, 4, 5, and 6, the hourly average values of surface refractivity plotted at 1-hour interval were observed to posses similar characteristics in dry season (January) and wet season (August) in both Minna and Lapai respectively. Figures 1, 2 and 3 represent the variations in a typical dry season month (January), which shows that surface refractivity have higher values in the morning (between 3:00- 9:00 Hours) and at night (between 21:00-23:00 Hours) owing to the decrease in temperature during that period of the day, and that surface refractivity falls in the afternoon (between 14:00-17:00 Hours) owing to the presence of sunshine during this period of the day.

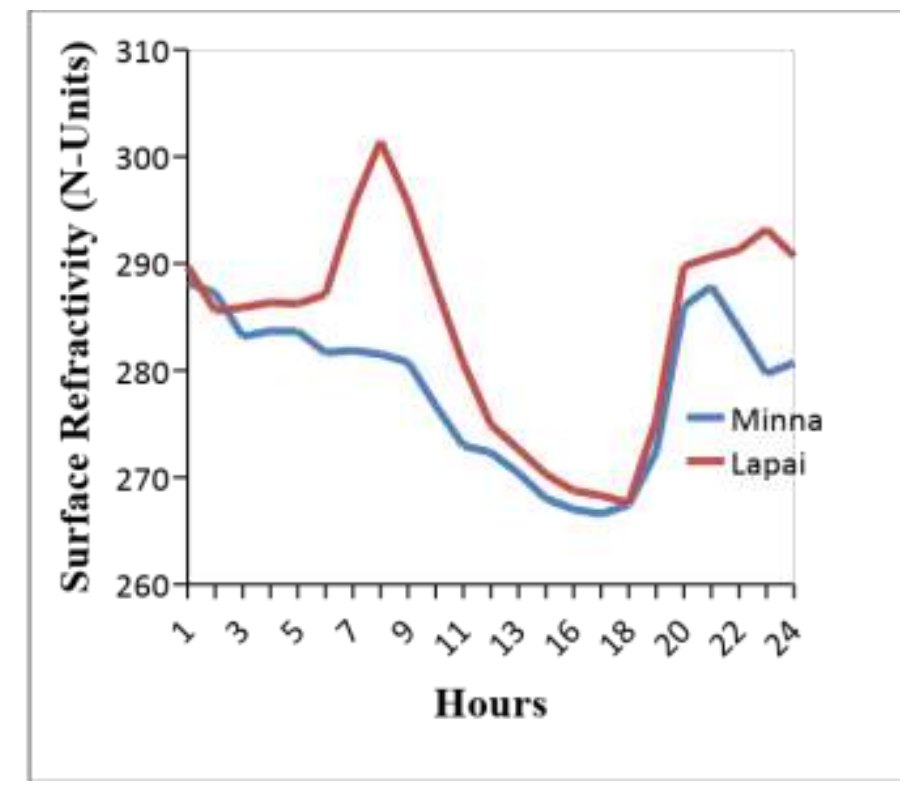

Figure 1: Diurnal variations of radio refractivity for a typical dry season month (January, 2011) 


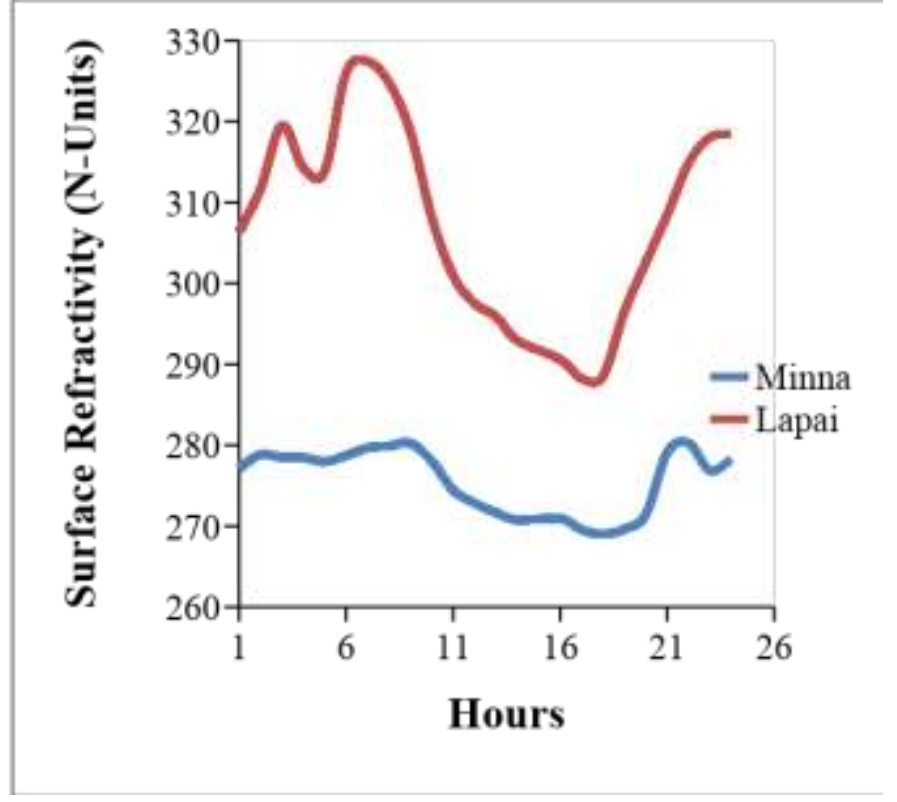

Figure 2: Diurnal variations of radio refractivity for a typical dry season month (January, 2012)

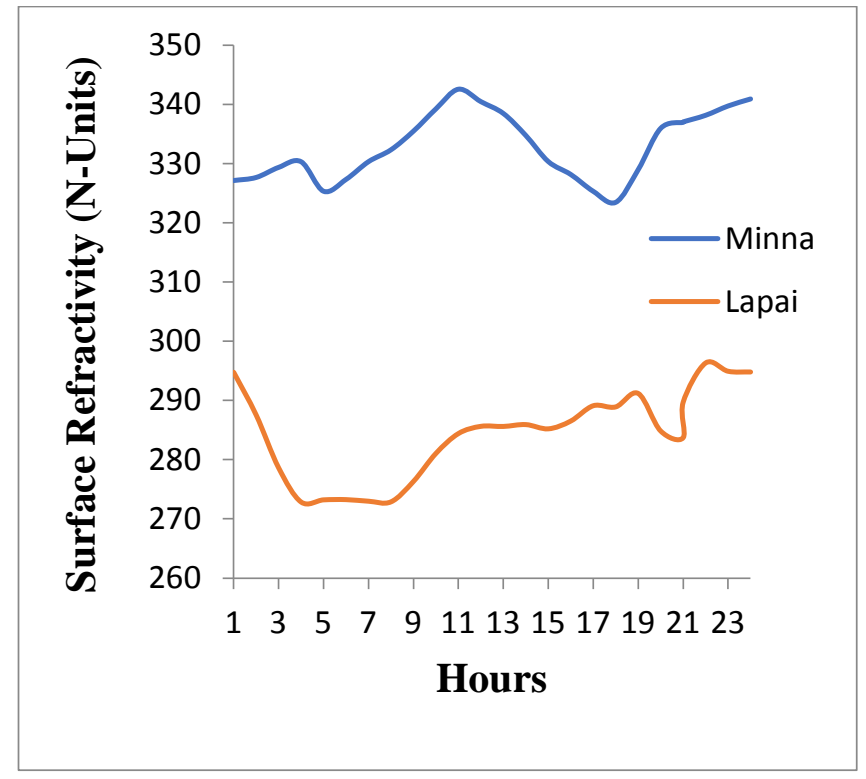

Figure 3: Diurnal variations of radio refractivity for a typical dry season month (January, 2013)

From the Figures 4, 5 and 6, which represent a typical wet season month, surface refractivity was found to have high values during early hours of the day between 1:00 - 10:00 Hours due to the fact that at the time, the troposphere (air) is typically subjected by high humidity which eventually increases humidity in the troposphere by resulting also to changes in surface refractivity. At day time hours between 15:00 - 17:00 Hours, a decrease in surface refractivity was observed corresponding to the period when there is sunshine and rises again at night between 20:00-23:00 Hours. 
Bashir Musa et. al., Diurnal and Seasonal Variation of Surface Refractivity

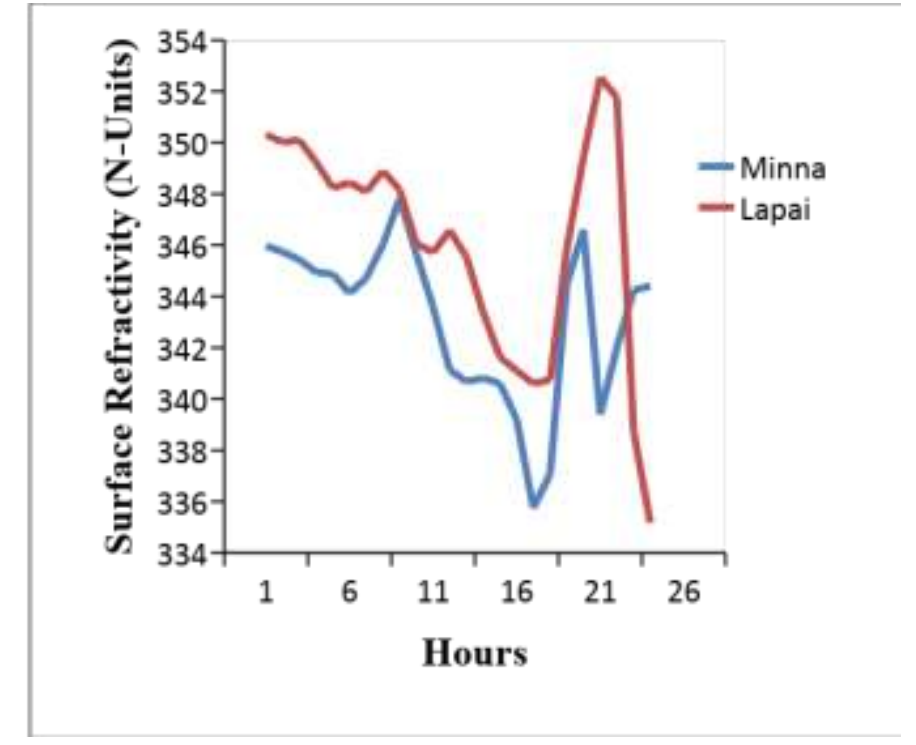

Figure 4: Diurnal variations of surface refractivity for a typical wet season month (August, 2011)

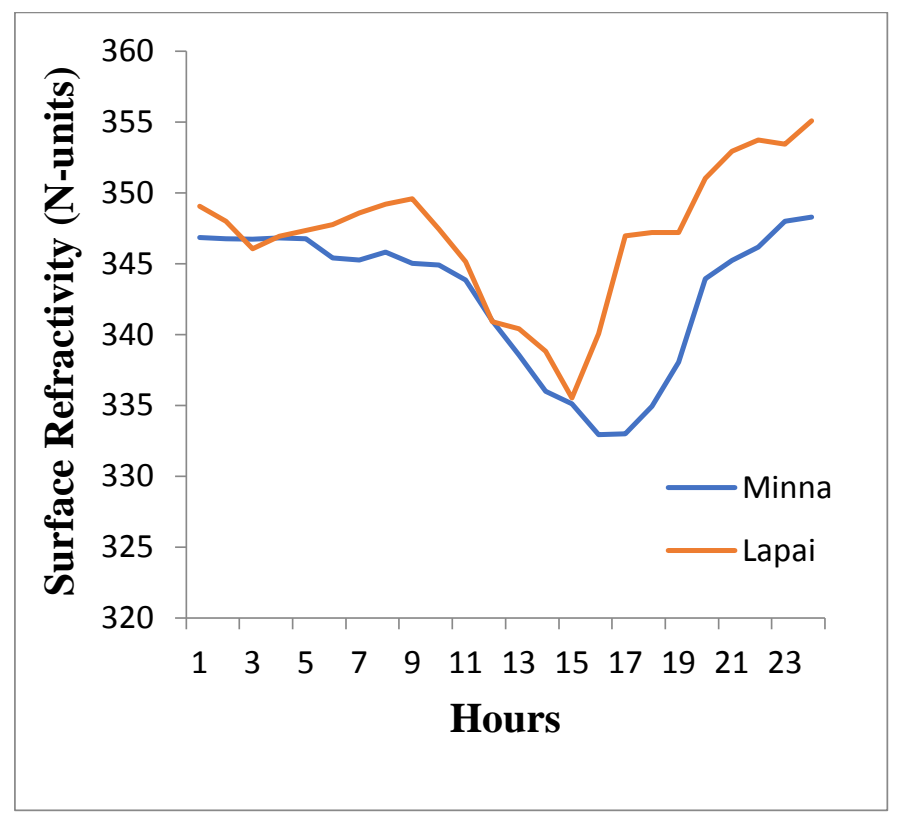

Figure 5: Diurnal variations of surface refractivity for a typical wet season month (August, 2012)

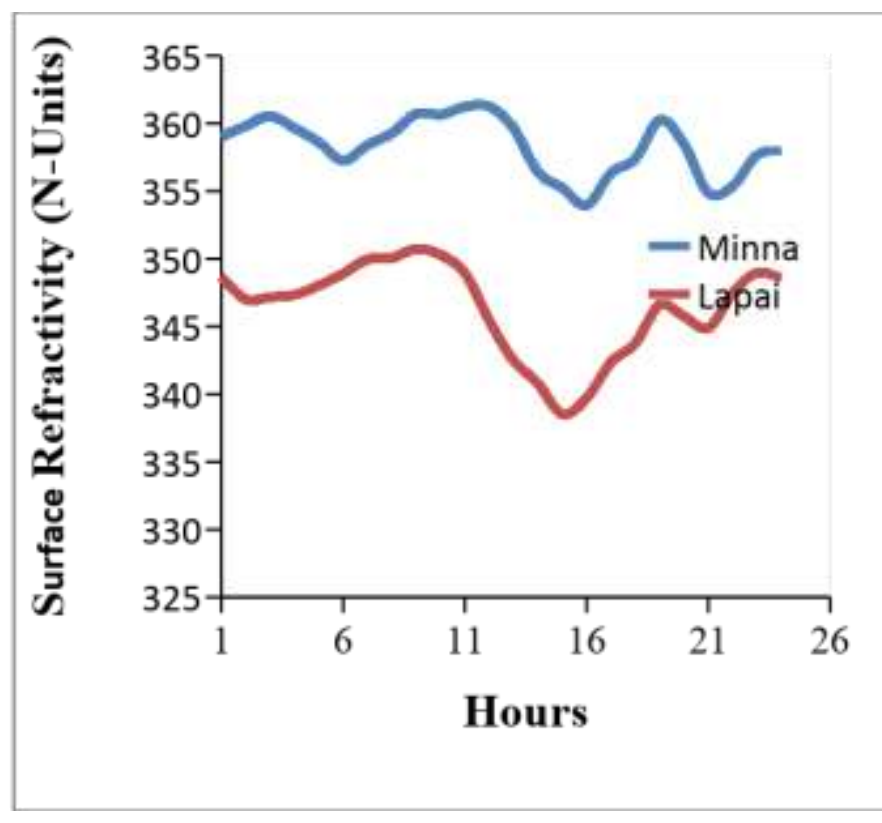

Figure 6: Diurnal variations of surface refractivity for a typical wet season month (August, 2013) 
The seasonal variation of surface refractivity for Minna and Lapai is shown in Figure 7. A maximum of $350 \mathrm{~N}$-units was observed in both locations in August, while minimum values of $275 \mathrm{~N}$-units in January in Minna and $278 \mathrm{~N}$-units in October were observed in Lapai in 2011.

Figure 4.8 shows the seasonal variation of surface refractivity at Minna and Lapai in 2012. In Minna, the minimum of $276 \mathrm{~N}$-units is observed in September, while the maximum of $343 \mathrm{~N}$-units is observed in July and August; in Lapai the minimum of $290 \mathrm{~N}$ units is observed in January while the maximum value of $347 \mathrm{~N}$-units occurred in August.

The seasonal variation of surface refractivity in Minna and Lapai in 2013 was plotted as shown in Figure 4.9. In Minna, the minimum of $273 \mathrm{~N}$-units occurred in January while the maximum of $353 \mathrm{~N}$-units occurred in October. In Lapai, the minimum of 297 N-units was observed in January, while the maximum of 349 N-units occurred in July and September in 2013.

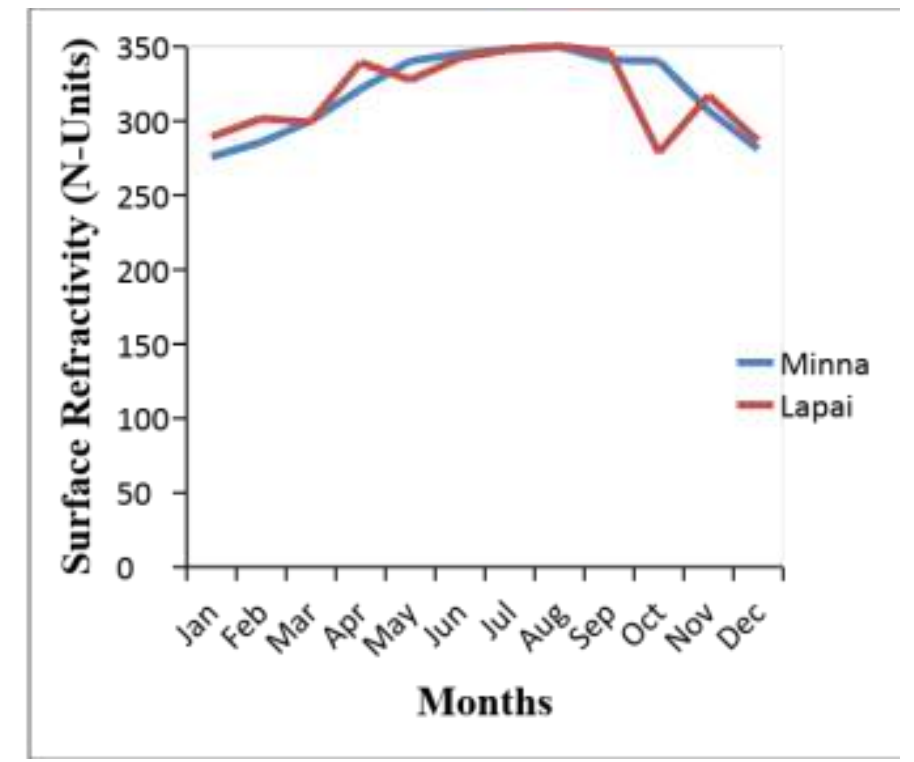

Figure 7: Seasonal variation of surface refractivity index in Minna and Lapai (2011)

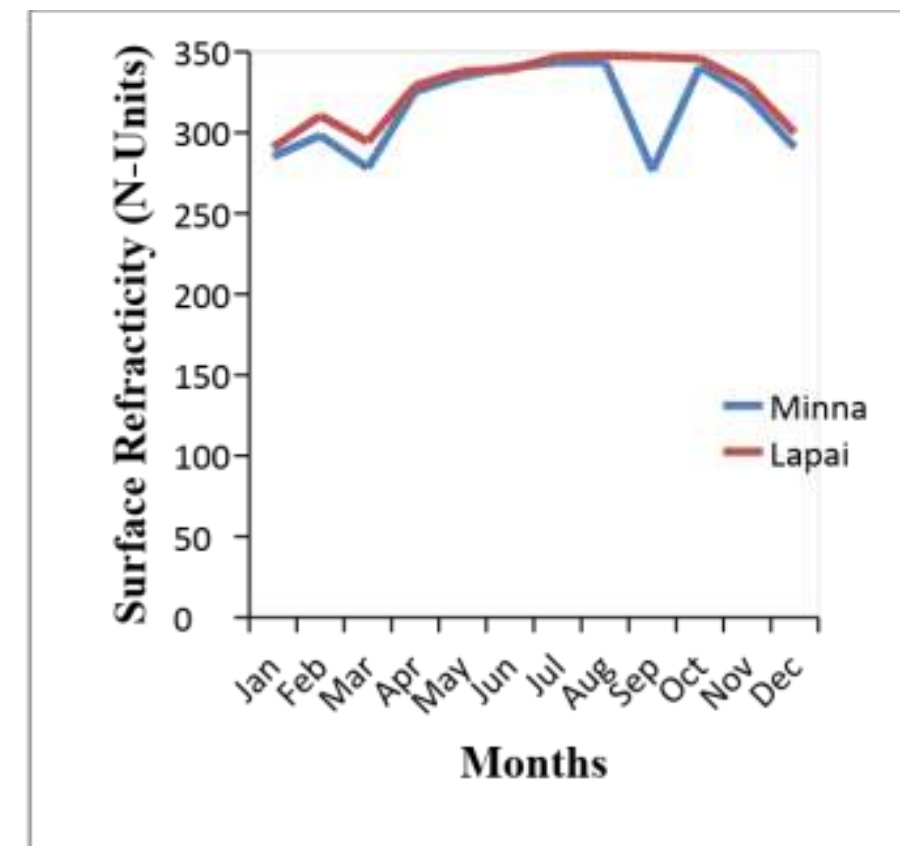

Figure 8: Seasonal variation of surface refractivity index in Minna and Lapai (2012) 
Bashir Musa et. al., Diurnal and Seasonal Variation of Surface Refractivity

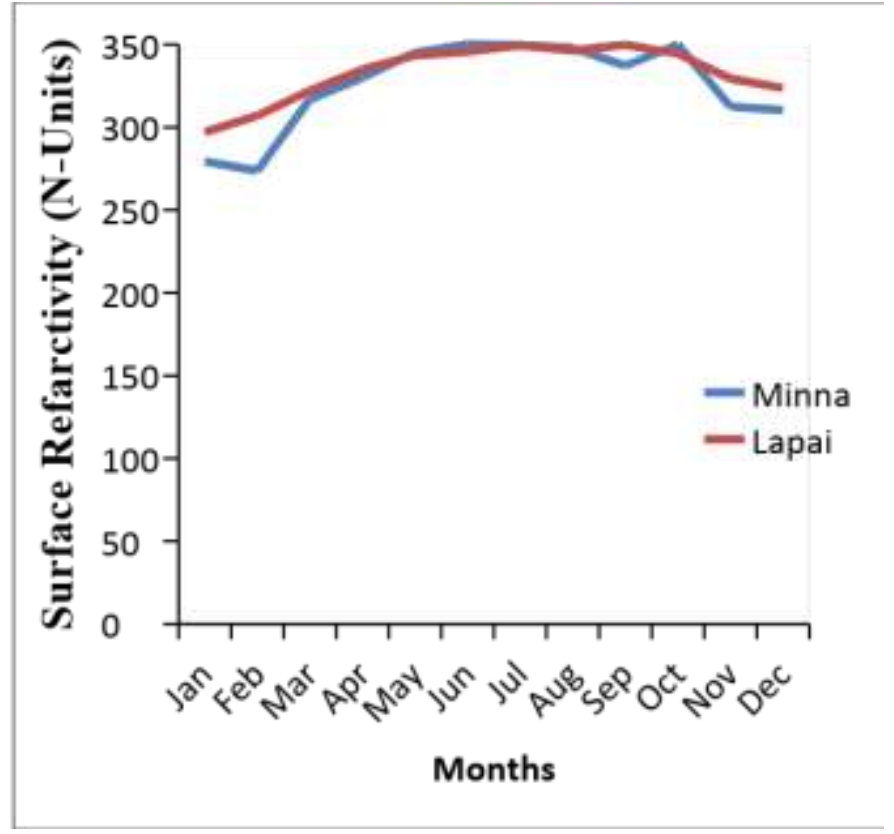

Figure 9: Seasonal variation of surface refractivity in Minna and Lapai (2013)

The seasonal variation of surface refractivity generally have lower values during the dry season months and higher values during the wet season months due to increase in humidity and decrease in temperature distributions in the troposphere. The high refractivity values in wet season confirmed the statement of Adediji (2008) and Oyedum et al. (2009) that refractivity values are observed to be generally high during the rainy season.

The average seasonal variation of surface refractivity consists of wet and dry seasons. In Minna and Lapai, April - October for wet season and November - March for dry season.

The average seasonal variation of wet term surface refractivity in Minna and Lapai was plotted and shown in Figure 10.

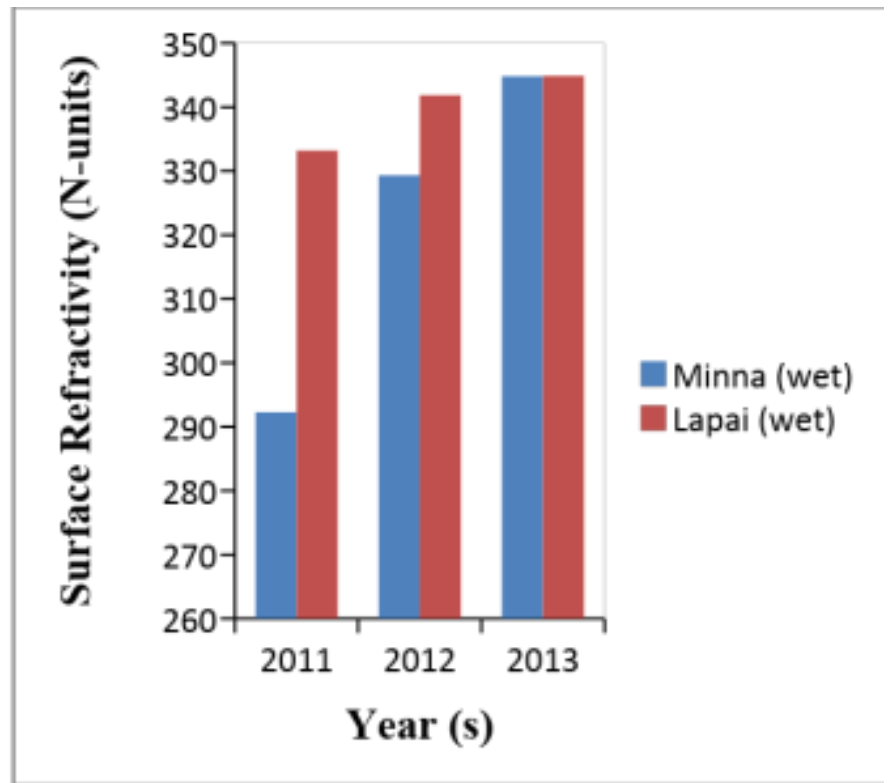

Figure 10: Average seasonal variations of wet term surface refractivity in Minna and Lapai (2011-2013) 


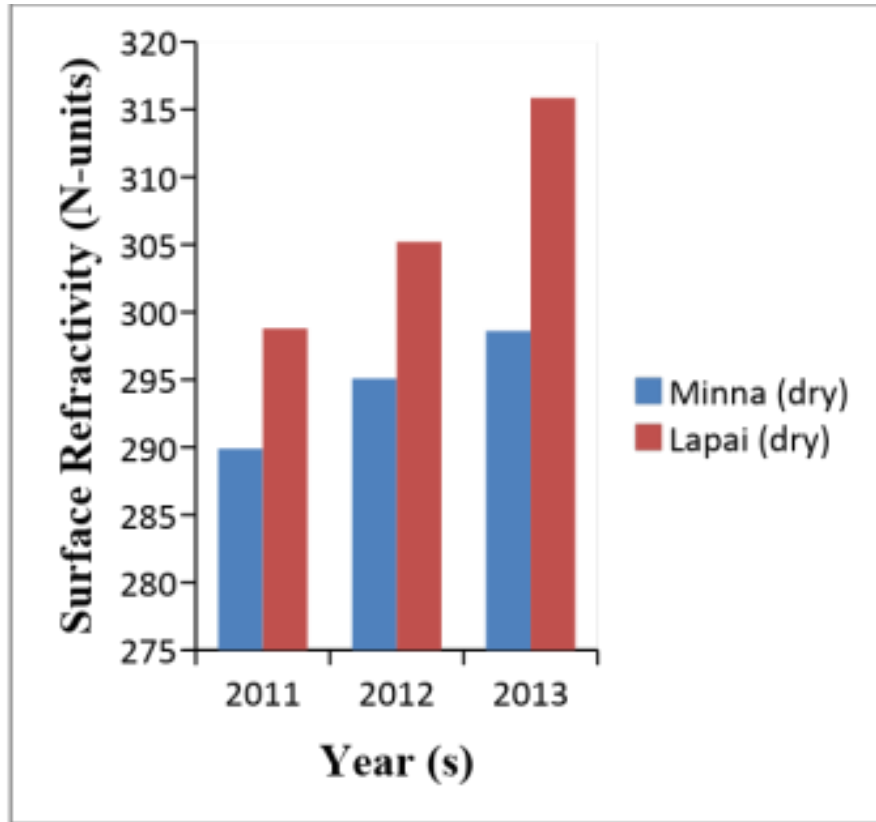

Figure 11: Average seasonal variations of dry term surface refractivity in Minna and Lapai (2011-2013)

Figure 10 show the average seasonal variation of wet term surface refractivity in Minna and Lapai (2011 - 2013). The wet term of average seasonal variation was observed to have a seasonal range of 290-345 N-units in Minna while 330-350 N-units were observed in Lapai in 2011-2013 respectively. The least variation of the wet term of surface refractivity occurred in Minna in 2011 (292.26 N-units) while the highest variations occurred in Minna and Lapai (344.88 N-units) in 2013 which is accompanied by high moisture contents in wet season in 2013 in the lower part of atmosphere. This high moisture content resulted in the changes of surface refractivity.

In Figure 11, the minimum value of $290 \mathrm{~N}$-units occurred in Minna in 2011 while the maximum of $316 \mathrm{~N}$-units was observed in 2013 in Lapai respectively. The dry term of surface refractivity variation in Minna was not as high as that of Lapai generally due to fact that Lapai is situated very close to reverine area than in Minna.

\section{CONCLUSION}

The study of surface refractivity and its effect in Minna and lapai in Nigeria is a very important as the parameter help in planning the communication links. The diurnal and seasonal patterns of the surface refractivity at Minna and Lapai are studied. The diurnal and seasonal pattern of surface refractivity distribution is due to surface meteorological parameters which also influences the surface refractivity. The diurnal result shows that surface refractivity were higher in the early morning and night hours; and lower values occurred during the day. The seasonal variation of the surface refractivity ranges between 270-350 N-units in both wet and dry seasons in both locations. On comparing the surface refractivity during wet and dry season, the value of surface refractivity during the wet season is higher than the surface refractivity during dry season.

\section{REFERENCES}

1. Adedeji, A. T., Ajewole, M. O., \& Oladosu, O. R. (2008). Radio Refractivity Measurement at 150m Altitude on TV Tower in Akure, South-West Nigeria. Journal of Engineering and Applied Sciences, 2(8), Medwell Journals, 1308-1313.

2. Adeyemi, B. (2006). "Surface water vapour density and tropospheric radio refractivity linkage over three stations in Nigeria," Journal of Atmospheric and Solar-terrestrial Physics, Vol. 68, No. 10, 1105-1115.

3. Ayantunji, B. G., Okeke, P. N. and Urama, J. O. (2011): Diurnal and Seasonal variations of surface refractivity over Nigeria. Progress in Electromagnetic Research B, vol. 30, 201 - 222.

4. Valma, E., Tamošiūnaitè, M., TamošiūTamošiūnienė, M., \& Žilinskas, M. S. (2010). Determination of radio refractive index using meteorological data Electronics and Electrical Engineering. Kaunas Technology. No. 10 (106). P. 125-128.

5. Aparicio, J. M., \& Laroche, S. (2011)."An evaluation of the Expression of the Atmospheric Refractivity for GPS signals". Journal of Geophysical Research. American Geophysical Union. 116 (D11): D11104.

6. Freeman, R. L. (2007). Radio system design for Telecommunications. Hoboken, New Jersey, 3rd edition, pp. 880, chapter 1, 5. ISBN 9780471757139. 
7. Webster, A. R. (1987).“Angle-of-arrival and tropospheric multipath propagation”, IEEE Transactions on Antenna and Propagation, Volume 35, No. 1, pp. 94-99.

8. Willoughby A. A., Aro T. O. and Owolabi I. E. (2002). Seasonal variations of radio refractivity gradients in Nigeria Journal of Atmospheric and Solar-Terrestrial Physics, 64, 417-425.

9. Adeyemi, B and Emmanuel, I (2011): Monitoring tropospheric radio refractivity over Nigeria using CM - SAF data derived from NOAA - 15, 16 and 18 satellites.

10. Oyedum, O. D., Moses, A. S., Igwe, K. C., and Eichie, J. O. (2009): Preliminary Results of Surface Refractivity in Minna, Niger State, Nigeria. Production of Annual Conference of Nigerian Union of Radio Science pp. 19-24.

11. Adedeji .T. A and Ajewole. M. O. (2008). Vertical Profile of Radio Refractivity in Akure south-West Nigeria, Vol. 4, p 157-168.

12. Adedeji, T. A. and M. O. Ajewole (2008). "Vertical profile of radio refractivity gradient in Akure, south-west Nigeria. Progress in Electromagnetics Research C, 4, 157-168.

13. Agunlejika, O. \& Raji, T. I. (2010). Empirical evaluation of wet -term of refractivity in Nigeria. Department of Electronic and Electrical Engineering Ladoke Akintola University of Technology, Ogbomoso, Nigeria. 